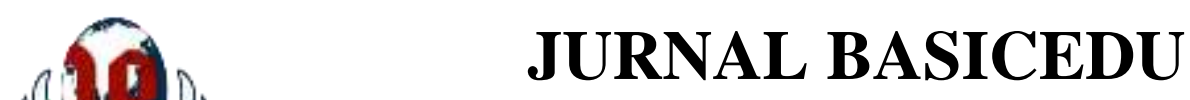

Volume 5 Nomor 5 Tahun 2021 Halaman 4120 - 4126

Research \& Learning in Elementary Education https://jbasic.org/index.php/basicedu

\title{
Pengaruh Metode Pembelajaran Diskusi dengan Tipe Buzz Group terhadap Keaktifan Belajar Siswa pada Mata Pelajaran IPS
}

\author{
Muhjam Kamza $^{1 凶}$, Husaini $^{2}$, Ayu Indah Lestari ${ }^{3}$ \\ Universitas Syiah Kuala, Banda Aceh, Indonesia ${ }^{1,2,3}$

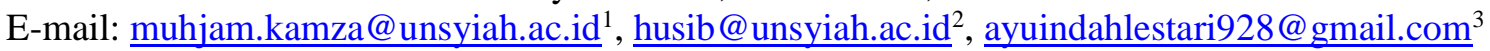

\begin{abstract}
Abstrak
Penelitian ini bertujuan untuk mengetahui pengaruh keaktifan belajar menggunakan metode pembelajaran diskusi tipe buzz group pada mata pelajaran IPS kelas VIII di SMP Negeri 1 Gunung Meriah. Penelitian ini menggunakan pendekatan kuantitatif dengan jenis peneitian true eksperimental dengan desain berfokus pada posttest-only control design yang mana pada desain ini terdapat dua kelompok. Populasi yang digunakan dalam penelitian ini adalah seluruh siswa kelas VIII yang terdiri dari 6 kelas sedangkan sampel dalam penelitian ini adalah siswa kelas VIII4 sebagai kelas eksperimen yang diajarkan dengan metode diskusi buzz group dan VIII5 sebagai kelas kontrol yang diajarkan dengan metode diskusi dengan jumlah siswanya masing-masing 20 orang. Teknik pengumpulan data dalam penelitian ini adalah dengan menggunakan observasi sebelum penelitian, angket, dan dokumentasi. Berdasarkan hasi penelitian diperoleh nilai dengan kriteria uji thitung > ttabel atau 5,425 > 2,024 pada taraf signifikansi (a) 5\% maka H0 ditolak atau terdapat pengaruh yang signifikansi metode pembelajaran diskusi dengan tipe buzz group terhadap keaktifan belajar siswa pada mata pelajaran IPS kelas VIII di SMP Negeri 1 Gunung Meriah.
\end{abstract}

Kata Kunci: Diskusi, Buzz Group, Keaktifan Belajar.

\begin{abstract}
This study aims to determine the effect of active learning using the buzz group type discussion learning method on social studies subjects for class VIII at SMP Negeri 1 Gunung Meriah. This study uses a quantitative approach with a true experimental type of research with a design focused on a posttest-only control design in which there are two groups in this design. The population used in this study were all students of class VIII which consisted of 6 classes while the samples in this study were students of class VIII4 as the experimental class who were taught by the buzz group discussion method and VIII5 as the control class which was taught by the discussion method the number of students each 20 people each. The data collection technique in this research is by using observation before the research, questionnaires, and documentation. Based on the results of the study obtained with test criteria tcount > ttable or $5.425>2,024$ at a significance level (a) maka5\% then $\mathrm{HO}$ is rejected or there is a significant influence on the method of discussion learning with the buzz group type on student activity in the subject Social Studies class VIII at SMP Negeri 1 Gunung Meriah.
\end{abstract}

Keywords: Discussion, Buzz group, active learning.

Copyright (c) 2021 Muhjam Kamza, Husaini, Ayu Indah Lestari

Corresponding author :

Email : muhjam.kamza@unsyiah.ac.id

DOI $\quad$ : https://doi.org/10.31004/basicedu.v5i5.1347

ISSN 2580-3735 (Media Cetak)

ISSN 2580-1147 (Media Online)

Jurnal Basicedu Vol 5 No 5 Tahun 2021

p-ISSN 2580-3735 e-ISSN 2580-1147 
4121 Pengaruh Metode Pembelajaran Diskusi dengan Tipe Buzz Group terhadap Keaktifan Belajar Siswa pada Mata Pelajaran IPS - Muhjam Kamza, Husaini, Ayu Indah Lestari

DOI: https://doi.org/10.31004/basicedu.v5i5.1347

\section{PENDAHULUAN}

Kemampuan partisipan didik bisa tumbuh dengan terdapatnya pendidikan. Konsep pendidikan sendiri ialah salah satu pokok berarti dalam kehidupan dimasyarakat serta dunia kerja, karenanya yang bersangkutan wajib sanggup mempraktikkan apa yang dipelajari ataupun apa yang dikenal disekolah supaya sanggup mengalami kasus yang dihadapinya dalam kehidupan tiap hari dikala ini ataupun yang hendak tiba (Trianto, 2012). Proses pendidikan berasal dari sekolah yang terlibat dalam proses pembelajaran. Belajar adalah proses, metode dan perilaku yang memotivasi siswa untuk belajar (Kartikasari, 2019). Berdasarkan pengertian tersebut dapat dikatakan proses pembelajaran adalah sebuah interaksi yang melibatkan guru dan siswa dalam melakukan komunikasi untuk mencapai tujuan belajar. Pembelajaran yang baik adalah pembelajaran yang dapat membuat suasana kelas menjadi kondusif, menyenangkan dan tidak membosankan. Salah satu cara untuk mendapatkan suasana tersebut adalah penggunaan cara atau metode yang tepat yang di terapkan di dalam kelas.

Dalam proses pembelajaran metode yang digunakan guru untuk membantu jalannya sebuah pembelajaran mempengaruhi keaktifan belajar peserta didik. Menurut Martinis Yamin (Sinar, 2018) kegiatan siswa dalam proses pembelajaran dapat merangsang dan mengembangkan bakatnya. Belajar diawali dengan terdapatnya dorongan, semangat, serta usaha yang mencuat dalam diri seorang sehingga orang itu melaksanakan aktivitas belajar. Aktivitas belajar yang dicoba membiasakan dengan tingkah lakunya dalam upaya bertambah keahlian dirinya. Dalam perihal ini, belajar sikap meningkatkan diri lewat proses perubahan prilaku (Majid, 2017). Berdasarkan penjelasan tersebut belajar dapat diartikan sebagai suatu penyesuaian tingkah laku atau penampilan melalui serangkaian kegiatan yang mereka dapat. Misalnya membaca, meniru, mendengar dan lain sebagainya.

Terkait penjelasan sebelumnya, berdasarkan observasi yang peneliti lakukan di SMP Negeri 1 Gunung Meriah terdapat permasalahan bahwa proses pembelajaran yang berlangsung kurang aktif dilihat dari kurangnya respons siswa dalam proses pembelajaran, salah satunya dalam ilmu sosial (IPS), hal ini dikarenakan saat guru memberi tugas dan membentuk kelompok dalam diskusi, Siswa mengalami kesulitan bekerja sama untuk memecahkan masalah yang berkaitan dengan materi yang diberikan oleh guru. Kemudian siswa masih malu dan takut dalam mengemukakan pendapat saat melakukan diskusi kelompok dengan anggota maupun bersama-sama. Oleh karena itu dibutuhkan metode pembelajaran yang tepat untuk dapat menghasilkan pembelajaran yang aktif dan menyenangkan.

Salah satu cara untuk mendorong siswa agar lebih aktif serta tertarik dalam proses belajar khususnya dalam IPS yaitu pembelajaran menggunakan metode diskusi dengan tipe buzz group karena dengan adanya metode ini mampu mendorong siswa untuk memberikan ide/pemikiran yang dapat meningkatkan partisipasi siswa yang masih belum bisa banyak bicara dalam berargumen serta menghargai pendapat orang lain (Nofalia, 2018). Penerapan buzz group dapat membuat siswa memperoleh umpan balik dengan cepat, serta memfasilitasi keterlibatan dengan topik didukung dengan meningkatkan keterlibatan siswa secara aktif dalam pembelajaran (Arivananthan, 2015).

Buzz group adalah diskusi yang bertujuan untuk membahas secara cepat suatu isu tertentu dengan cara mendiskusikannya dari perspektif yang berbeda (Ahmadi \& Prasetya, 2019). Pengertian lain mengenai buzz group yaitu dengan membagi siswa menjadi beberapa kelompok. Jumlah anggota kelompok adalah 3-5 orang. Pelaksanaannya dimulai dengan guru menyajikan masalah secara keseluruhan dan masalah tersebut dipecahkan menjadi submasalah yang harus dipecahkan oleh setiap subkelompok. Dalam diskusi kelompok kecil, fasilitator mempresentasikan hasil diskusi (Majid, 2017). Dapat di simpulkan metode pembelajaran dengan tipe buzz group adalah metode yang mampu membantu siswa mengembangkan kepercayaan diri dalam mengemukakan pendapat sehingga siswa lebih aktif dalam kelompok. 
4122 Pengaruh Metode Pembelajaran Diskusi dengan Tipe Buzz Group terhadap Keaktifan Belajar Siswa pada Mata Pelajaran IPS - Muhjam Kamza, Husaini, Ayu Indah Lestari

DOI: https://doi.org/10.31004/basicedu.v5i5.1347

Buzz group ialah metode diskusi biasa dengan membagi siswa menjadi beberapa kelompok. grup ini memiliki 3-5 anggota (Zahara, Dhien N, Zaharah, \& Arif, 2020). Perwujudannya dimulai dengan guru secara umum menyajikan masalah, yang kemudian dibagi menjadi sub-sub masalah yang harus dipecahkan oleh setiap subkelompok. Setelah diskusi kelompok kecil, ketua kelompok akan mengumumkan hasil diskusi (Fernando \& Marikar, 2017; Sanjaya, 2019). Metode buzz group juga dapat dilakukan pada kondisi ruangan yang berisik, karena masing-masing kelompok disibukkan dengan katifitas diskusi yang aktif antar sesamanya (Arslantosun, 2021; Pangaribuan \& Manik, 2017).

Berdasarkan beberapa pendapat sebelumnya, dapat disiimpulkan bahwa buzz group merupakan diskusi kelompok besar yang dibagi menjadi kelompok-kelompok kecil sekitar 3-5 orang untuk membantu siswa berdiskusi dan bertukar pikiran serta mengungkapkan pandangan mereka tentang materi diskusi dan metode diskusi dengan tipe buzz group juga dapat membuat siswa lebih aktif serta fokus dalam pembelajaran sehingga meningkatkan keaktifan belajar siswa. Dengan adanya keaktifan ini juga akan memberikan stimulus terhadap kerja akal dan keinginan siswa untuk menemukan berbagai persoalan dalam konteks pembelajaran hingga menemukan solusi terhadap permasalahan tersebut serta menyimpulkan hasil temuannya sehingga menjadi sebuah produk pembelajran yang komprehensif (Dadi \& Kewa, 2021).

Ketika menggunakan metode pembelajaran buzz group, ada langkah-langkah yang harus didahului dan di pahami, adapun langkah-langkah buzz group adalah sebagai berikut: 1) Guru menjelaskan sekilas tentang materi yang diajarkan; 2) Guru membagi beberapa anggota dalam forum kecil yang terdiri dari 3-5 orang; 3) Setelah masing-masing kelompok sudah terbentuk, tiap kelompok mengerjakan pemberian tugas, terdapat yang berprofesi seperti pemimpin forum, penulis/pencatatdan mencari bahan bacaan/ informasi; 4) Tiap forum ditugasi membincangkan materi dari aspek pemikiran tertentu (tugas ditentukan oleh guru); 5) Anggota dari setiap kelompok juga harus mencari informasi dari kelompok lain dan saling bertukar informasi; 6) Menetukan waktu yang digunakan untuk pembahasan; 7) Selesai pembahasan dalam kelompok, setiap kelompok diberi giliran menyampaikan hasilnya yang diatur oleh pimpinan universal; 8) Pencatat universal mencatat serta muat kesimpulan dari masing-masing kelompok; dan 9) Pada waktu ulasan kelompok berlangsung, guru bisa berpindah-pindah dari kelompok yang satu ke kelompok yang lain, sambil memberikan pengarahan bila diperlukan (Ahmadi \& Prasetya, 2019).

Dalam sebuah proses pembelajaran guru belum sepenuhnya membuat siswa lebih aktif berdiskusi dalam kelompok, masih adanya siswa yang malu dalam menyampaikan pendapat/ ide sehingga mempengaruhi keaktifan dalam proses pembelajaran. Keaktifan siswa dalam hal ini keseriusan siswa dalam mematuhi subjek dapat dilihat (Sinar, 2018). Keaktifan belajar merupakan hal penting yang dapat meningkatkan keberhasilan belajar dengan menekankan siswa akan berpartisipasi langsung dalam pembelajaran disertai dengan adanya antusiasme pada diri peserta didik tersebut (Yunitasari \& Hardini, 2020).

Keterlibatan langsung siswa diukur melalui adanya indikator-indikator yang termuat dalam keaktifan belajar. Menurut Nana Sudjana (Salo, 2017), evaluasi proses pendidikan dan pembelajaran terutama untuk melihat seberapa aktif siswa terlibat dalam proses pendidikan dan pembelajaran, dan aktivitas siswa adalah (1) keikutsertaan siswa dalam melaksanakan tugas; (2) pemecahan masalah melibatkan peserta, dll; (3) keterlibatan peserta didik dalam mencari informasi; (4) kerjasama dan hubungan sosial; (5) Menilai kemampuan dirinya dan partisipasi siswa dalam proses tanya jawab.

Peneliti berpendapat metode pembelajaran diskusi dengan tipe buzz group diterapkan secara efektif sehingga akan tercipta suasana kelas yang aktif serta memperkuat pemahaman peserta didik terhadap apa yang diperoleh dalam diskusi, dengan demikian mampu membantu siswa untuk lebih tetap fokus akan kemampuan yang dimilikinya. Pada dasarnya bentuk keaktifan ini juga dapat kita perhatikan ketika peserta didik tersebut ikut berkontribusi dalam penyelesaian dalam sebuah permasalahan serta memiliki keinginan untuk bertanya ketika ada hal yang tidak dimengerti (Prasetyo \& Abduh, 2021). 
4123 Pengaruh Metode Pembelajaran Diskusi dengan Tipe Buzz Group terhadap Keaktifan Belajar Siswa pada Mata Pelajaran IPS - Muhjam Kamza, Husaini, Ayu Indah Lestari

DOI: https://doi.org/10.31004/basicedu.v5i5.1347

Berdasarkan berbagai gambaran dan argumen diatas, maka kajian dalam penentuan ini bertujuan untuk mengetahui apakah susunan pembelajaran diskusi jenis buzz group berpengaruh terhadap kegiatan belajar peserta didik kelas VIII pada mata pelajaran IPS di SMP Negeri 1 Gunung Meriah. Terkait dalam hal ini peneliti merumuskan masalah sebagai berikut yaitu apakah susunan pembelajaran diskusi dengan jenis buzz group berpengaruh terhadap keaktifan belajar peserta didik kelas VIII pada mata pelajaran IPS di SMP Negeri 1 Gunung meriah.

\section{METODE}

Penelitian ini memakai pendekatan kuantitatif dengan jenis penelitian true eksperimental dengan desain berfokus pada posstest only control design yang mana pada desain ini terdapat dua kelompok. Cara pengumpulan sampel dilakukan secara sampling purposive yaitu teknik penentuan sampel dengan pertimbangan tertentu (Sugiyono, 2012). Guru yang mengajar sama, kurikulum sama, mata pelajaran satu kelas, dan tingkat kemahirannya sama karena sampel dianggap homogen. Cara ini dipilih dengan jumlah sampel yang berasal dari populasi dalam penelitian sebanyak 40 siswa. Mereka kemudian dibagi menjadi dua kelompok yang masing-masing terdiri dari 20 siswa. Kelompok pertama seluruh siswa kelas VIII4 sebagai kelas eksperimen yang diajarkan dengan metode diskusi buzz group dan VIII5 sebagai kelas kontrol yang diajarkan dengan metode diskusi.

Data ini menargetkan keaktifan peserta didik dalam ilmu sosial (IPS) pada kelas VIII yang dikumpulkan dengan menggunakan angket sebagai instrumen untuk melihat kegiatan peserta didik dalam pembelajaran ilmu pengetahuan sosial. Sebelum digunakan, angket terlebih dahulu diuji kevalidannya dengan uji validitas dan uji reabilitas dengan bantuan IBM SPSS versi 22.

Setelah dilakukan pengujian angket dapat dilihat dari nilai r-tabel yang berjumlah 0,361 ditentukan oleh r-product moment dari buku (Sugiyono, 2017) bila jumlah responden kuesioner ditanyakan pada taraf signifikansi 5\%. Dari 30 item pernyataan tes, 15 item yang valid diterima. Berdasarkan hasil yang diperoleh, peneliti memutuskan untuk menggunakan semua elemen klaim valid yang didistribusikan untuk kelas eksperimen dan kontrol.

\section{HASIL DAN PEMBAHASAN}

Perbedaan keaktifan belajar siswa antara kedua kelas tersebut ditemukan sehubung dengan ketetapan analisis data penelitian yang dilakukan di SMP Negeri 1 Gunung Meriah pada kelas VIII4 sebagai kelas eksperimen dan kelas VIII5 sebagai kelas kontrol $56 \geq 45$ kecenderungan, tergolong sangat tinggi. Klasifikasi tersebut didasarkan pada tabel klasifikasi keaktifan siswa dan perangkat pembelajaran, yang diklasifikasikan menurut indikator keaktifan pembelajaran. Siswa terlihat lemah. Berdasarkan jenis aktivitas belajar siswa pada kelompok bawah $37,5>33 \geq 30$, perbedaan tersebut tentunya disebabkan oleh beberapa faktor dalam cara belajar.

Rendahnya partisipasi peserta didik dalam proses pelajaran di kelas kontrol tidak mendorong penggunaan metode pembelajaran biasa untuk mendorong siswa berpartisipasi dalam pembelajaran sekaligus seaktif mungkin dalam kecerdasan fisik, emosional, dan fisik. fakta bahwa itu Proses Metode diskusi buzz group mendorong siswa untuk aktif secara fisik, emosional dan intelektual. Hal ini didukung dengan mendorong langkah-langkah metodologi bimbingan yang menunjuk peserta didik untuk terlibat bersungguhsungguh dalam belajar sepanjang hayat. Ini memberi siswa pemahaman yang lengkap tentang materi, kesempatan untuk bertanya dan menjawab pertanyaan, dan mendorong mereka untuk berpartisipasi dalam peran masing-masing dalam pembelajaran. Pendekatan pembelajaran ini mendorong siswa untuk bekerja 

pada Mata Pelajaran IPS - Muhjam Kamza, Husaini, Ayu Indah Lestari

DOI: https://doi.org/10.31004/basicedu.v5i5.1347

secara individu maupun kelompok untuk mencapai tujuan pembelajarannya. Proses kegiatan yang relevan dan bermakna ini juga dapat memungkinkan siswa dapat belajar secar aktif (Hartnett, 2016).

Pembelajaran jenis buzz group merupakan cara belajar kelompok yang berdampak besar pada pembagian persoalan serta dapat menumbuhkan keterlibatan peserta didik. Dalam pembelajaran berbasis permasalahan, peserta didik berbagi peran dan tugas dalam kelompok untuk memecahkan masalah yang disajikan oleh guru. Siswa berpartisipasi dalam proses pemecahan masalah. Ada juga kerjasama kelompok dan interaksi antara peserta didik dan pendidik dalam pemisahan persoalan (Arivananthan, 2015; Cantillon, 2003; Tyas, 2018).

Metode pembelajaran diskusi dengan tipe buzz group juga memiliki kelebihan dan kekurangan. Kelebihan buzz group ialah: 1) Pembelajaran aktif; 2) Memperkuat sikap kooperatif antar kelompok; 3) Mempromosikan pertukaran siswa dan ekspresi ide; 4) Mendukung peserta didik mengambil keputusan; 5) Mengembangkan pengetahuan baru untuk membentuk pertanyaan diskusi; 6) Mengembangkan sikap menghargai pendapat orang lain yang menumbuhkan semangat belajar siswa; 7) Meningkatkan kepercayaan diri siswa untuk mengungkapkan pendapatnya dalam forum diskusi; 8) Menuntut sikap bertanggung jawab terhadap pekerjaan guru. Sedangkan kekurangan dari penggunaan metode pembelajaran diskusi dengan tipe buzz group ialah : 1) Metode ini membutuhkan waktu; 2) Susunan ini tidak akan beruntung jika anggota setiap kelompok tidak mengetahui tugas atau peran yang diberikan oleh guru (Tyas, 2018). Dari argumen tersebut dapat kita simpulkan maka pembelajaran kelompok diskusi ialah kegiatan yang memungkinkan orang pemalu untuk berbagi pikiran dan pendapat serta menciptakan suasana yang positif.

Berdasarkan percobaan normalitas yang dikerjakan sebaran data pada kelas eksperimen dan kelas kontrol berdistribusi normal. Berdasarkan hasil ouput IBM SPSS versi 22 pada Tabel 1. diperoleh jumlah nilai chi-square sebesar 0,900 dan angka signifikansi sebesar $1.000>0,05$ maka dapat digaris bawahi bahwa data berdistribusi normal.

Tabel 1. Uji Normalitas

\begin{tabular}{rr}
\hline & Unstandardized Residual \\
\hline Chi-Square & $.900^{\mathrm{a}}$ \\
\hline Df & 18 \\
\hline Asymp. Sig. & 1.000 \\
\hline
\end{tabular}

Berdasarkan percobaan homogenitas varians menurut kelas eksperimen maupun kelas kontrol, dasar pengambilan ketuntasan dalam uji homogenitas varians, jika taraf signifikansi $>0,05$ maka. karena nilai 0,808 $>0,05$, bahwa dasar pengambilan keputusan dalam uji homogenitas di atas, dapat dikatakan bahwa varians data hasil angket keaktifan siswa kelas VIII4 dan VIII5 adalah sama atau homogen.

Tabel 2. Uji Homogenitas

\begin{tabular}{cccc}
\hline $\begin{array}{c}\text { Levene } \\
\text { Statistic }\end{array}$ & df1 & df2 & Sig. \\
\hline .060 & 1 & 38 & .808 \\
\hline
\end{tabular}

Berdasarkan hasil percobaan hipotesis atau uji-t yang dilakukan dalam penelitian ini, terdapat perbedaan yang signifikan antara keaktifan belajar siswa menggunakan metode pembelajaran diskusi tipe buzz group dan metode diskusi biasa. Pada pengujian hipotesis yang dilakukan diperoleh nilai $\mathrm{t}$ hitung $>\mathrm{t}$ tabel atau $5,425>2,024$.

\section{Coefficients $^{\mathrm{a}}$}


4125 Pengaruh Metode Pembelajaran Diskusi dengan Tipe Buzz Group terhadap Keaktifan Belajar Siswa pada Mata Pelajaran IPS - Muhjam Kamza, Husaini, Ayu Indah Lestari

DOI: https://doi.org/10.31004/basicedu.v5i5.1347

\begin{tabular}{|c|c|c|c|c|c|c|}
\hline \multirow{2}{*}{\multicolumn{2}{|c|}{ Model }} & \multicolumn{2}{|c|}{$\begin{array}{c}\text { Unstandardized } \\
\text { Coefficients }\end{array}$} & \multirow{2}{*}{$\begin{array}{c}\begin{array}{c}\text { Standardized } \\
\text { Coefficients }\end{array} \\
\text { Beta }\end{array}$} & \multirow{2}{*}{$\mathbf{T}$} & \multirow{2}{*}{ Sig. } \\
\hline & & B & $\begin{array}{c}\text { Std. } \\
\text { Error }\end{array}$ & & & \\
\hline \multirow[t]{2}{*}{1} & (Constant) & 60.886 & 11.224 & & 5.425 & .000 \\
\hline & Kontrol & -.152 & .240 & -.147 & -.631 & .536 \\
\hline
\end{tabular}

Dengan demikian, sesuai kriteria pengujian maka H0 diterima. Artinya terdapat perbedaan yang signifikan antara keaktifan belajar siswa menggunakan metode pembelajaran diskusi tipe buzz group dan metode diskusi biasa, dan pada penelitian ini keaktifan belajar siswa yang diajarkan menggunakan metode pembelajaran diskusi tipe buzz group lebih baik dari pada hasil belajar siswa yang diajarkan menggunakan metode diskusi biasa.

\section{KESIMPULAN}

Dari hasil penelitian mengenai bagian cara belajar diskusi menggunakan buzz group pada kegiatan pendidikan mata pelajaran IPS, dapat disimpulkan bahwa penggunaan metode pembelajaran diskusi dengan menggunakan buzz group berpengaruh terhadap belajar siswa tertentu. Siswa dapat berpartisipasi aktif secara fisik, emosional, dan fisik. Kekayaan intelektual dalam proses pembelajaran. Selain itu untuk mencapai indikator kinerja tertentu dalam pembelajaran siswa dan pencapaian tujuan akademik.

Secara umum pada kelas eksperimen siswa memiliki tingkat aktivitas belajar IPS yang sangat tinggi yaitu 56\% dengan kecenderungan sangat tinggi yaitu $56 \geq 37,5+7,5=56 \geq 45$ yaitu terhadap indikator kemajuan atau keaktifan belajar. Partisipasi siswa yang dicapai oleh kelompok kontrol adalah $33 \%$ yang cenderung 37,5 $>33 \geq 37,5-1.7,5=37,5>33 \geq 30$ dan tergolong rendah menurut tabel aktivitas belajar peserta didik, yang menunjukkan bahwa partisipasi siswa dalam proses pembelajaran belum mencapai Kegiatan belajar peserta didik. Oleh karena itu, penggunaan metode pembelajaran diskusi dengan jenis buzz group berpengaruh signifikan terhadap kegiatan belajar siswa kelas VIII mata pelajaran IPS SMP Negeri 1 Gunung Meriah.

\section{UCAPAN TERIMA KASIH}

Dalam penyusuna penelitian ini penulis mengucapkan puji beserta syukur kepada Allah SWT atas segala rahmat dan nikmat-Nya telah memberikan kemudahan kepada penulis untuk menyelesaikan penelitan ini, peneliti juga mengucapkan terimakasih kepada kepala sekolah SMP Negeri 1 Gunung Meriah, Aceh Singkil yang telah memberikan izin dalam melakukan penelitian ini.

\section{DAFTAR PUSTAKA}

Ahmadi, A., \& Prasetya, J. T. (2019). Strategi Belajar Mengajar Untuk Fakultas Tarbiyah Komponen Mkdk. Bandung: Cv. Pustaka Setia.

Arivananthan, M. (2015). Knowledge Exchange Toolbox: Group Methods For Sharing, Discovery And CoCreation. Knowledge Exchange Unit, In The Policy, Strategy And Networks Section, In Unicef's Division Of Data, Research And Policy (Dpr). Retrieved From Https://Www.Unicef.Org/KnowledgeExchange/Files/Unicef_Knowledge_Exchange_Toolbox.Pdf

Arslantosun, B. (2021). Buzz GrutekniĞi: Çok BoyutlubiR Araştirma. Turkish Journal Of Educational 
4126 Pengaruh Metode Pembelajaran Diskusi dengan Tipe Buzz Group terhadap Keaktifan Belajar Siswa pada Mata Pelajaran IPS - Muhjam Kamza, Husaini, Ayu Indah Lestari

DOI: https://doi.org/10.31004/basicedu.v5i5.1347

Research, 2(1), 11-18. Https://Doi.Org/10.51242/Saka-Tjer.2021.8

Cantillon, P. (2003). Abc Of Learning And Teaching In Medicine Teaching Large Groups. Bmj, 326(7386), 437-440. Https://Doi.Org/10.1136/Bmj.326.7386.437

Dadi, A. F. P., \& Kewa, M. (2021). Penerapan Model Pembelajaran Time Token Dalam Upaya Meningkatkan Keaktifan Belajar Ppkn Peserta Didik Di Sekolah Dasar. Jurnal Basicedu, 5(1), 357-366. Https://Doi.Org/Https://Doi.Org/10.31004/Basicedu.V5i1.703

Fernando, S. Y., \& Marikar, F. M. (2017). Constructivist Teaching/Learning Theory And Participatory Teaching Methods. Journal Of Curriculum And Teaching, 6(1), 110 Https://Doi.Org/10.5430/Jct.V6n1p110

Hartnett, M. (2016). Motivaton In Online Education. Singapore: Springer Nature.

Kartikasari, A. (2019). Pengaruh Media Pembelajaran Kokami (Kotak Kartu Misterius) Terhadap Keaktifan Dan Hasil Belajar Siswa Kelas Vii Pada Mata Pelajaran Ips Di Smp Negeri 20 Semarang. Universitas Negeri Semarang.

Majid, A. (2017). Strategi Pembelajaran (7th Ed.). Bandung: Pt Remaja Rosdakarya.

Nofalia, I. (2018). Pengaruh Metode Brainstorming, Buzz Group, And Simulation (Bbs) Terhadap Pengatahuan, Sikap, Dan Tindakan Merokok Pada Remaja. Universitas Airlangga.

Pangaribuan, T., \& Manik, S. (2017). The Effect Of Buzz Group Technique And Clustering Technique In Teaching Writing At The First Class Of Sma Hkbp I Tarutung. English Language Teaching, 11(1), 164. Https://Doi.Org/10.5539/Elt.V11n1p164

Prasetyo, A. D., \& Abduh, M. (2021). Peningkatan Keaktifan Belajar Melalui Discovery Learning Di Sekolah Dasar. Jurnal Basicedu, 5(4), 1717-1724. Https://Doi.Org/Https://Doi.Org/10.31004/Basicedu.V5i4.991

Salo, Y. A. (2017). Pengaruh Metode Discovery Learning Terhadap Keaktifan Belajar Siswa (Studi Quasi Eksperimen Kelas Vii Smpn 6 Banda Aceh). Jurnal Penelitian Pendidikan, 16(3), 297-304 Https://Doi.Org/10.17509/Jpp.V16i3.4825

Sanjaya, W. (2019). Strategi Pembelajaran Berorientasi Standar Proses Pendidikan. Jakarta: Kencana Prenada Media.

Sinar. (2018). Metode Active Learning. Yogyakarta: Deepublish (Cv Budi Utama).

Sugiyono. (2012). Metode Penelitian Pendidikan Pendekatan Kuantitatif, Kualitatif, Dan R\&D (15th Ed.). Bandung: Alfabeta.

Sugiyono. (2017). Statistika Untuk Penelitian (28th Ed.). Bandung: Alfabeta.

Trianto. (2012). Mendesain Model Pembelajaran Inovatif- Progresif(1st Ed.). Jakarta: Prenada Media Group.

Tyas, S. L. N. (2018). Pengaruh Metode Buzz Group Discussion Dengan Permainan Rolet Terhadap Kemampuan Kerjasama Dan Kemampuan Memecahkan Masalah Pada Mata Pelajaran Ips (Quasi Ekperimen Pada Siswa Di Kelas Viii Smp Islam Al-Hikmah). Uin Syarif Hidayatullah.

Yunitasari, I., \& Hardini, A. T. A. (2020). Penerapan Model Pbl Untuk Meningkatkan Keaktifan Peserta Didik Dalam Pembelajaran Daring Di Sekolah Dasar. Jurnal Basicedu, 3(2), 524-532.

Zahara, S., Dhien N, C., Zaharah, Z., \& Arif, M. (2020). Metode Buzz Group Discussion Dengan Permainan Rolet Membentuk Kemampuan Kerjasama Dan Kemampuan Memecahkan Masalah Pada Mata Pelajaran Ips. Rausyan Fikr: Jurnal Pemikiran Dan Pencerahan, 16(1), 14-22. Https://Doi.Org/10.31000/Rf.V16i1.2419 